\title{
Influence of Entertainment Media, Cognitive Styles and Demographic Variables on Students' Reading Habits in Yaba College of Technology Secondary School, Yaba, Lagos
}

\author{
Beatrice Oluwakemi Adeyokun ${ }^{1}$ \\ Elkana Oyetunde Adeyanju² \\ George Ogheneruemu Onyenania ${ }^{3}$ \\ Yaba College of Technology Library \\ Yaba-Lagos Nigeria ${ }^{1,2} \& 3$
}

\begin{abstract}
The study sought to examine the "Influence of Entertainment Media, Cognitive Styles and Demographic Variables on Students' Reading Habits in Yaba College of Technology Secondary School, Yaba-Lagos". The survey correlation research design was adopted to establish the relationship among the study variables. Targeted population of the study is 627 students consisting of 302 and 325 JSS and SSS students in the 2018/2019 academic session. 200 students were sampled representing $32 \%$ of its total population, upon whom 200 copies of the study questionnaire were drawn via multistage sampling techniques. Complete data collected from 198 respondents were analysed quantitatively using appropriate descriptive and inferential statistics via SPSS version 20.0 to answer the study research questions and test formulated hypothesis while criteria mean was placed at 2.50 level of significance to record the following major findings: Entertainment media utilized by students such as smartphones, internet via laptops and television had significant positive influence their reading habits; likewise their cognitive styles and demographic variables. The study therefore recommends that management of Yaba College of Technology Secondary School should ensure that entertainment media resources be adequately made available for students' use especially at the school library media resource centre under close monitoring while considering their cognitive styles and demographic variables to enhance their reading habits among others.
\end{abstract}

Keywords: Students Reading Habit, Library, Entertainment Media, Cognitive Styles, Demographic Variables,

\section{Introduction}

Effective learning is a key factor to national growth and development. Reading habit is a critical factor in the achievement of effective leaning. The formal education sector plays vital role in this regard. Reading habit is a two component words. In the first place, reading can be seen as an art of recognition and interpretation of printed or written words that facilitates communication among people. Existing literature has shown that reading is one of the four human language skills throughout ages; while the other three are writing, listening and speaking. Thus, Singh (2013:1) defines reading as "an art of interpreting printed and written works" or "an active attempt on the part of a reader to understand a writer's message". Reading has also been described as the process of looking at, and comprehending the meaning of written and printed words from visual representation of symbols. Reading takes place when the reader 
Influence of entertainment media, cognitive styles and demographic variables on students' reading habits in Yaba College of Technology secondary school, Yaba, Lagos

understands what has been encoded. Thus, comprehension is at the centre of reading.

Reading is therefore fundamental to the acquisition of knowledge necessary for effective living either at the individual level, community or national level especially among students who are often regarded as the leaders of tomorrow. The common saying "readers are leaders" assumes relevance and attests to this ideal. The axioms "Reading is power! Read a book today! Reading maketh a man! Teach a child to read ... and you have made a king!" (Adeyanju, 2016). These common axioms further emphasize the place of reading in the general development of man and society. Literature has shown that individuals who read well already possess immense tools for competitive life advantages via increase in their intellectual capacities for effective exploration of economic opportunities towards successful living and peaceful co-existence. Thus, reading empowers the change desired by an individual for capacity building, innovativeness, creativity, psychomotor skills, edifies the psyche, makes the brain sharper which could cause such individual to voyage far devoid of movement through deep thinking or abstraction; and facilitates teaching/learning process which has saved and advanced the human race over the years (Adeyanju, 2016; Braunger \& Lewis,
2006). Effective reading has indeed spurs positive learning, emotional and intellectual outcome as well as development among people who do not only understand the value of it but actively engages in it. This phenomenon further reveals the importance of reading most especially among students. The degree and pattern or nature of reading in an individual translates to such an individual's reading habit.

Reading habit can be regarded as somebody's characteristics, culture or unique way of reading usually developed overtime. Thus, Owusu-Acheaw and Larson (2014:2) described "reading habit as well-planned and deliberate pattern of study which has attained a form of consistency on the part of a reader or student toward understanding academic subjects and passing at examinations". Reading habits goes a long way in determining students' academic success. It was reported that reading habit usually has strong link or influence on students' academic achievements (Owusu-Acheaw \& Larson, 2014). There are different types of reading habits such as independent reading habits, group reading, daily or everyday reading habit, reading only when exams are at hand among others. Thus, reading habit could either be good or poor depending on the individual and 
Influence of entertainment media, cognitive styles and demographic variables on students' reading habits in Yaba College of Technology secondary school, Yaba, Lagos

circumstances around the reader. These circumstances and several other salient factors influence a person's reading habit such as access to entertainment media or facilities, cognitive style, and demographic variables among others.

\section{Entertainment media are} information gargets and resources capable of providing amusement and assist in reducing tension among people. Entertainment media are of different types such as films, magazines, leisure books, radio, television, internet social platforms among others. They come in form of movies, TV shows, theatre, video games, radio shows, news, music, newspapers, magazines and books. Entertainment media especially those operated on social electronic platforms are recently playing indispensable roles in students' reading and learning behaviour both at home and at school wherein modern entertainment media is resident (Abbas, Aman, Nurunnabi \& Bano, 2019). However, entertainment media appears to be having significant negative influence on students' academic achievements including their reading habits in most recent times. Thus, Singh (2013) asserted that "nowadays, a common allegation is raised that reading habits among students is decreasing and poor" and that "if we go to the reading room of a library these days, we find most of the seats are dusty" (not utilized) which could have resulted from students' addition to online entertainment media use. Meanwhile, if entertainment media devices and platforms are cautiously utilized among students especially under close monitoring, it would no doubt have positive influence on their learning outcome through appropriate blend with reading activities. The reverse could also be the case (negative influence) if misused which could occur in the absence of necessary guidance especially among young adults wherein the secondary school students age brackets falls. Thus, it is increasingly observed in existing literature that entertainment media via social networking sites and their applications present enormous benefits, as well as risks to students and their implications on students' psychological adjustment, learning and reading behaviours (Abbas, Aman, Nurunnabi \& Bano, 2019). This claim is one of the bases of this study. Put differently, cognitive styles among students could have significant influence on their reading habits.

Cognitive style could be seen as the way in which a learner organizes and processes new information or knowledge (Lu, 2015). To this end, cognitive styles possessed by learners or students could affect their choice of learning strategies 
Influence of entertainment media, cognitive styles and demographic variables on students' reading habits in Yaba College of Technology secondary school, Yaba, Lagos

including those pertaining to their reading habits (Lu, 2015:2). He emphasized that cognitive styles play important roles in students' learning process upon which reading habits revolves. In essence, students' cognitive styles could influence their reading habits.

Moreover, other factors such as the learners' demographic backgrounds could also have significant influence on their reading habits. In a study of learners or students' differences, it was expressed that factors such as gender, age, aptitude, and motivational levels are important variables which may influence the learning process wherein reading habit is central (Mokhtari \& Reichard, 2004; as cited in Lu, 2015). The importance of all these variables projected above, informed the focus of the current study with the aim of establishing the influence of Entertainment Media, Cognitive Styles and Demographic Variables on Students' Reading Habits in Yaba College of Technology Secondary School, Yaba, Lagos.

\section{Statement of the Problem}

Effective learning is a key factor to national growth and development. Viable nations of the world do not underrate issues of learning especially those pertaining to the formal education sector wherein the issues of reading habits and learning facilities are not only seen as essential, but adequately provided and encouraged for positive academic outcome. The situation appears different in developing countries such as Nigeria. Ofcourse, the researchers' personal observations and existing literature have shown that reading habits among students in Nigeria is not only becoming poor but rapidly decreasing and having negative impact on their academic achievements. It was also reported that if we go to most library reading rooms in Nigeria these days, we would find that most of the seats are dusty. This presupposes low usage of library resources which may have resulted from poor reading habits among students. This scenario is becoming a great source of worry to all stakeholders particularly among teachers and librarians. This phenomenon could be due to several factors especially those connected with students' addiction or over-engagements with entertainment media in recent times; as well as those relating to their cognitive styles and demographic backgrounds. Thus, this study examines the influence of entertainment media, cognitive style and demographic variables on students' reading habits in Yaba College of Technology (Yabatech) Secondary School, Yaba-Lagos. 


\section{Research Questions}

The following research questions were raised to guide study:

I. What are the reading habits possessed by Yaba College of Technology Secondary School students?

II. What is the influence of entertainment media used by Yaba College of Technology Secondary School students on their reading habits?

III. What is the influence of the dominant cognitive style among Students of Yaba College of Technology Secondary School on their reading habits?

\section{Research Hypothesis}

$\mathbf{H}_{\mathbf{0}}$ : Entertainment media use, Students' cognitive style and demographic variables do not significantly influence the reading habits of Yaba College of Technology Secondary School Students.

\section{Literature Review}

Several works have pointed out the relevance of reading habits on students' academic achievements. Some others have equally shown the degree at which educational facilities or teaching aids impacts on students' success, as well as the influence of demographic variables influence on their performance. First and foremost is the study conducted by
Adeoye and Popoola (2011) on educational media resources utilisation among students wherein they emphasized that educational media is necessary for effective learning which could appear in both print and electronic forms such as course readings materials, recordings, magazines, smart phones, television, radio, Internet and related gadgets among others.

Igbokwe, Obidike and Ezeji (2012) examined the effect of electronic media on reading aptitude of primary and secondary school pupils. Their results showed that 93\% of the students spent less than one hour each day reading in relation to $70 \%$ of them that spent a least of two hours in playing games on mobile phones. A survey research carried out in Britain established that youngsters, matured in the vicinity of 11 and 18 years, stare at the TV or utilize the Internet than read books (Mori, 2004). The writing survey recommends that few variables, especially innovative changes are probably going to impact reading propensities of young people. It was recorded that students are in the habit of engaging in social reading experiences both among content area educators/teachers and their colleagues in classrooms and display such group reading intension in library environment (Donaldson, 2013). This is an indication that students have the habit of group 
Influence of entertainment media, cognitive styles and demographic variables on students' reading habits in Yaba College of Technology secondary school, Yaba, Lagos

reading. The study conducted by Abbas, Aman, Nurunnabi and Bano (2019), disclosed that the use of social and entertainment media alike in Pakistan had negative influence on students' learning and reading behaviour as compared to the positive aspects of it. In an earlier study directed by Menorca, Idos, Manangan \& Patacsil, 2017; cite Gross, 2009), it was emphasized that "people now found themselves in the use of entertainment media gadgets very frequently especially through modern digital technologies both at home and at workplaces and are finding it difficult to survive in the absence of modern means of entertainment media and communications as people and institutions of learning are now relying heavily on these digital devices for information, education, and entertainment as well as for social interactions" (Menorca, Idos, Manangan \& Patacsil, 2017).

It has been argued that computer and related technologies affect college students' reading habits (Kumara \& Kuma, 2018) who claimed that "the computer revolution is significantly affecting reading habits in the perspective of history and current literacy trends; and that researchers believed that computers and the Internet are changing the way people read. In addition, Shen (2006) earlier disclosed that "this new media and its entertainment platforms online where digital literacy campaign belongs is affecting the reading habits of the people of all ages including students". It was presently indicated that "computer and related information communication gadgets are integrated into almost every aspect of learning in higher education and their institutional library whereby textbooks arrive with CD-ROMs; homework is delivered and graded on the World Wide Web (WWW); and assignments are designed to be completed collaboratively through electronic mail; noting that: the Internet has become an important part of college students' lives, not only for their studies and daily routines, but as a tool for entertainment and getting to know other people and the rest of the world". Hence today, classrooms are equipped with modern/latest technologies to enhance instructions wherein laptop and desktop computers, internet and television, as well as cell-phones' use among others are becoming imperative in classrooms and relative environment such as the library inspite of the fact that cell-phone usage in this platforms is still somewhat controversial (Menorca, Idos, Manangan \& Patacsil, 2017).

Moreover, some reports had established students waste long times watching the television, surfing the net 
Influence of entertainment media, cognitive styles and demographic variables on students' reading habits in Yaba College of Technology secondary school, Yaba, Lagos

rather than reading their textbooks thereby changing reading culture among students (Loan, 2012; Majid \& Tan, 2007). They observed that these technologies; computer and related contraptions, digital TV, Internet, video and $\mathrm{PC}$ recreations, talk rooms and online journals are catching learners' attention and time and are getting to be keen contenders with books with which the learners have been earlier comfortable with. This, if not properly controlled could lead to a serious drop in students' reading habits; while others believe that the Internet is a welcome phenomenon as it makes students' work easier. Afangideh and Jude (2012) and Onovughe (2012) reported that the Internet ameliorates the tediousness of students' academic work. This observation can only be true if the Internet is used for positive purposes. Meanwhile, in a survey of "the Internet and cell-phone addiction of 910 Taiwan college students, Chou and Hsiao (2000) as cited by Shen (2006:560) found that college students who are addicted to the Internet spent an average of 17.66 hours weekly, 6.58 hours on the WWW, 3.47 hours on e-mail, and 5.47 hours on games/entertainment every week". This circumstance, is not only reshaping reading habits among students but their cognitive style of learning.
Cognitive style could be seen as the way in which a learner organizes and processes new information or knowledge (Lu, 2015). To this end, cognitive styles possessed by learners or students could affect their choice of learning strategies including those pertaining to their reading habits (Lu, 2015:2). To this end, Alpern (2009) expressed that "readers usually bring various cognitive abilities, linguistic skills and capabilities, as well as experiences and dispositions to the act of reading; noting that good readers possess decoding skills, vocabulary and grammar knowledge; and that students have knowledge of various topics and discourse types, and utilizes cognitive skills in monitoring comprehension and resist possible comprehension's breakdown". Cognitive styles play important roles in students' learning process upon which reading habits revolves (Lu, 2015). In essence, Lu (2015) believed that students' cognitive styles could influences students' reading habits.

Moreover, other factors such as the learners' demographic backgrounds could also have significant influence on their reading habits. In a study of learners or students' differences, it was expressed that factors such as gender, age, aptitude, and motivational levels are important variables which may influence the learning process 
Influence of entertainment media, cognitive styles and demographic variables on students' reading habits in Yaba College of Technology secondary school, Yaba, Lagos

wherein reading habit is central (Mokhtari \& Reichard, 2004; as cited in Lu, 2015). Although works on the study variables seem to be exhaustive in nature, but none of them treated nor combined the influence of the three independent variables on students' reading habits as captured in this current study.

\section{Methodology}

The correlational survey research design was employed for the study. Targeted population of the study is JSS and SSS students in the 2018/2019 academic session. The study population consisted of six hundred and twenty-seven (627) JSS I to SSS III students with the respective aggregate population of 302 and 325 for JSS and SSS students (i.e. 95 for JSS I, 98 for JSS II, 109 for JSS III; while SSS I has 93, SSS II has 124, and 108 for SSS III respectively). The multistage sampling techniques was adopted for the study. First, 200 respondents representing $32 \%$ of the total population of the study was purposively sampled representing 100 Presentation of Data and Analysis

Research question 1: What are the reading habits possessed by Yaba College of Technology Secondary School students?

Table 1: Reading Habits

\begin{tabular}{lllllllll}
\hline Item statements & & SA & A & D & SD & Tot & Mean & Decision \\
\hline \hline 1. I only read when I have examination & $\mathrm{F}$ & 68 & 59 & 32 & 39 & 198 & 2.97 & Accept \\
& $\%$ & 34.3 & 29.8 & 16.2 & 19.7 & 100 & & \\
2. I read in the company of friends. & $\mathrm{F}$ & 55 & 45 & 49 & 49 & 198 & 2.54 & Accept \\
& $\%$ & 27.8 & 22.7 & 24.7 & 24.7 & 100 & &
\end{tabular}


Influence of entertainment media, cognitive styles and demographic variables on students' reading habits in Yaba College of Technology secondary school, Yaba, Lagos

3. I don't feel satisfied until I have read it several times and for many days.

4. I enjoy reading at daytime.

5. I prefer reading in isolation.

6. My usual daily reading period is more than an hour

7. I prefer reading class note books to textbooks.

8. I often take my spare time to read books.

40. I read always to be well informed.

9. I prefer reading at home than in school library.

10. I enjoy reading at night

11. I always take reading as a serious task

12. I take note while reading.

13. I enjoy reading in a quiet place

\section{Overall Mean/Cluster Mean (2.92)}

\section{Source: Field Survey, 2019}

Table 1 showed the mean ratings on cognitive style scale. Based on the cut-off point of 2.50 criteria mean of the study, the data on Table 1 therefore revealed that: participants agreed they only read when they have examinations in company of friends and they don't feel satisfied until they have read several times and for many days. The participants agreed that they $\begin{array}{llllllll}\text { F } & 63 & 78 & 29 & 28 & 198 & 3.81 & \text { Accept }\end{array}$

$\begin{array}{llllll}\% & 31.8 & 39.4 & 14.6 & 14.1 & 100\end{array}$

$\begin{array}{llllllll}\text { F } & 52 & 49 & 48 & 49 & 198 & 2.61 & \text { Accept }\end{array}$

$\begin{array}{llllll}\% & 26.3 & 24.7 & 24.2 & 24.7 & 100\end{array}$

$\begin{array}{llllllll}\text { F } & 52 & 51 & 43 & 52 & 198 & 3.01 & \text { Accept }\end{array}$

$\begin{array}{llllll}\% & 26.3 & 25.8 & 21.7 & 26.3 & 100\end{array}$

$\begin{array}{llllllll}\text { F } & 87 & 78 & 18 & 15 & 198 & 3.88 & \text { Accept }\end{array}$

$\begin{array}{llllll}\% & 43.9 & 39.4 & 9.1 & 7.6 & 100\end{array}$

$\begin{array}{llllllll}\text { F } & 65 & 87 & 25 & 21 & 198 & 2.72 & \text { Accept }\end{array}$

$\begin{array}{llllll}\% & 32.8 & 43.9 & 12.6 & 10.6 & 100\end{array}$

$\begin{array}{llllllll}\text { F } & 71 & 86 & 24 & 17 & 198 & 2.69 & \text { Accept }\end{array}$

$\begin{array}{llllll}\% & 35.9 & 43.4 & 12.1 & 8.6 & 100\end{array}$

$\begin{array}{llllllll}\text { F } & 70 & 73 & 28 & 27 & 198 & 2.82 & \text { Accept }\end{array}$

$\begin{array}{llllll}\% & 35.4 & 36.9 & 14.1 & 13.6 & 100\end{array}$

$\begin{array}{llllllll}\text { F } & 51 & 47 & 54 & 48 & 200 & 2.12 & \text { Reject }\end{array}$

$\begin{array}{llllll}\% & 25.8 & 23.7 & 27.3 & 24.2 & 101\end{array}$

$\begin{array}{llllllll}\text { F } & 57 & 53 & 48 & 40 & 198 & 2.73 & \text { Accept }\end{array}$

$\begin{array}{llllll}\% & 28.8 & 26.8 & 24.2 & 20.2 & 100\end{array}$

$\begin{array}{llllllll}\text { F } & 65 & 71 & 34 & 28 & 198 & 2.55 & \text { Accept }\end{array}$

$\begin{array}{llllll}\% & 32.8 & 35.9 & 17.2 & 14.1 & 100\end{array}$

$\begin{array}{llllllll}\text { F } & 81 & 75 & 21 & 21 & 198 & 3.12 & \text { Accept }\end{array}$

$\begin{array}{llllll}\% & 40.9 & 37.9 & 10.6 & 10.6 & 100\end{array}$

$\begin{array}{llllllll}\text { F } & 89 & 88 & 12 & 9 & 198 & 3.37 & \text { Accept }\end{array}$

$\begin{array}{llllll}\% & 44.9 & 44.4 & 6.1 & 4.5 & 100\end{array}$

Accept 
Influence of entertainment media, cognitive styles and demographic variables on students' reading habits in Yaba College of Technology secondary school, Yaba, Lagos

key findings of this study as it shows the importance of library use among secondary school students since it reveals that students don't prefer reading at home than at the library. Put differently, students prefer reading at the library than at home. Surprisingly, respondents indicated that they prefer reading class notebooks to textbooks as stocked by libraries. This form of reading habit among secondary school students could be due to several reasons not covered in this study. Thus, it calls for continuous library development and sustainability to enthrone better reading habits among students towards improved academic achievements. In a brief statement, the respondents or students have good reading habits since the average score is well above the cut-off point of 2.50 on Table 1. This finding is however contrary to that of Singh (2013) who asserted that "nowadays, a common allegation is raised that reading habits among students is poor and decreasing. This difference could be attributed to several reasons not covered in this study which could form basis for future research.

Research question 2 What is the influence of entertainment media used by Yaba College of Technology Secondary School students on their reading habits?

\section{Table 2: Entertainment media utilization}

\begin{tabular}{|c|c|c|c|c|c|c|c|c|}
\hline \multicolumn{2}{|l|}{ Questionnaire Items } & $\mathbf{S A}$ & $\mathbf{A}$ & $\mathbf{D}$ & SD & Tot & Mean & Decision \\
\hline 1. I learn unconsciously from using a & $\mathrm{F}$ & 253 & 94 & 33 & 18 & 198 & \multirow{2}{*}{3.87} & \multirow[t]{2}{*}{ Accept } \\
\hline cell/smart phone (via e.g. Social Media). & $\%$ & 26.8 & 47.5 & 16.7 & 9.1 & 100 & & \\
\hline \multirow{2}{*}{$\begin{array}{l}\text { 2. I feel that using a cell/smart phone } \\
\text { improves my vocabulary. }\end{array}$} & $\mathrm{F}$ & 71 & 87 & 21 & 19 & 198 & \multirow[t]{2}{*}{3.91} & \multirow[t]{2}{*}{ Accept } \\
\hline & $\%$ & 35.9 & 43.9 & 10.6 & 9.6 & 100 & & \\
\hline \multirow{2}{*}{$\begin{array}{l}\text { 3. I learn unconsciously from internet use via } \\
\text { laptops \& other computer devices. }\end{array}$} & $\mathrm{F}$ & 88 & 74 & 18 & 18 & 198 & \multirow[t]{2}{*}{3.63} & \multirow[t]{2}{*}{ Accept } \\
\hline & $\%$ & 44.4 & 37.4 & 9.1 & 9.1 & 100 & & \\
\hline \multirow{2}{*}{$\begin{array}{l}\text { 4. I learn unconsciously from watching } \\
\text { television. }\end{array}$} & $\mathrm{F}$ & 64 & 59 & 42 & 33 & 198 & \multirow[t]{2}{*}{2.51} & \multirow[t]{2}{*}{ Accept } \\
\hline & $\%$ & 32.3 & 29.8 & 21.2 & 16.7 & 100 & & \\
\hline \multirow{3}{*}{$\begin{array}{l}\text { 5. Using the internet via computer devices } \\
\text { improves my vocabulary despite the fact that } \\
\text { I did not make any effort to improve on my } \\
\text { vocabulary. }\end{array}$} & $\mathrm{F}$ & 51 & 56 & 45 & 46 & 198 & \multirow[t]{3}{*}{2.50} & \multirow[t]{3}{*}{ Accept } \\
\hline & $\%$ & 25.8 & 28.3 & 22.7 & 23.2 & 100 & & \\
\hline & & & & & & & & \\
\hline 6. Watching television improves my scope of & $\mathrm{F}$ & 72 & 47 & 37 & 42 & 198 & \multirow[t]{2}{*}{3.21} & \multirow[t]{2}{*}{ Accept } \\
\hline $\begin{array}{l}\text { knowledge despite the fact that I did not } \\
\text { make effort to do so. }\end{array}$ & $\%$ & 36.4 & 23.7 & 18.7 & 21.2 & 100 & & \\
\hline 7. I regularly use cell/smart phone to share & $\mathrm{F}$ & 61 & 58 & 41 & 38 & 198 & \multirow[t]{2}{*}{4.02} & \multirow[t]{2}{*}{ Accept } \\
\hline $\begin{array}{l}\text { education media information with my } \\
\text { classmates. }\end{array}$ & $\%$ & 30.8 & 29.3 & 20.7 & 19.2 & 100 & & \\
\hline 8. Watching television improves my & $\mathrm{F}$ & 53 & 54 & 50 & 41 & 198 & \multirow[t]{2}{*}{2.57} & \multirow[t]{2}{*}{ Accept } \\
\hline vocabulary despite the fact that I did not & $\%$ & 26.8 & 27.3 & 25.3 & 20.7 & 100 & & \\
\hline
\end{tabular}


Influence of entertainment media, cognitive styles and demographic variables on students' reading habits in Yaba College of Technology secondary school, Yaba, Lagos

$\begin{array}{lllllllll}\text { 9. I get current information from listening to } & \mathrm{F} & 56 & 69 & 45 & 28 & 198 & 3.25 & \text { Accept } \\ \text { radio. } & \% & 28.3 & 34.8 & 22.7 & 14.1 & 100 & & \\ \begin{array}{l}\text { 10. I get current information from watching } \\ \text { television without any effort. }\end{array} & \mathrm{F} & 52 & 48 & 51 & 47 & 198 & 2.48 & \text { Reject } \\ \begin{array}{l}\text { 11. I get current information from using the } \\ \text { internet with less stress. }\end{array} & \mathrm{F} & 84 & 87 & 13 & 14 & 198 & 3.97 & \text { Accept } \\ \text { Overall Mean/Cluster Mean (3.27) } & \% & 42.4 & 43.9 & 6.6 & 7.1 & 100 & & \end{array}$

\section{Source: Field Survey, 2019}

Table 2 showed the mean ratings on entertainment media utilization. The data indicates that the mean ratings of items. Based on the cut-off point of 2.50 criteria mean of the study, the data on Table 2 therefore revealed that: entertainment media have strong influence on secondary school students' reading habits. This is so because all rated items were accepted except item 10. Thus, Table 2 indicates that participants learn unconsciously from using a cell/smart phone (via e.g. Social Media platforms), participants also feel that using a cell/smart phone improves their vocabulary, and that they learn unconsciously from using the internet and from watching television. Respondents also accepted that using the internet improves their vocabulary despite the fact that they didn't make any effort to improve on their vocabulary, and that watching television improves their scope of knowledge in spite of the fact that they didn't make efforts to do so. Table 2 also revealed that participants regularly use cell/smart phone to share education media information with their classmates, and that watching television improves their vocabulary despite the fact that they did not make any conscious effort towards their vocabulary increase; and that respondents get current information from using cell/smart phones in getting current information from the internet with less stress; while they rejected the statement that they get current information from watching television without any effort among others. The findings are clear indications that entertainment media positively influence the reading habits of secondary school students. The finding is in support of that of Adeoye and Popoola (2011) and Menorca, Idos, Manangan and Patacsil (2017) whose studies respectively reported that Entertainment Media resources use is necessary for effective learning process; and that such Entertainment Media assets can be in both printed and electronic formats; and that technology-based Entertainment Media such as the cell-phone and television were the major types used by students since technology use is revolutionising the education sector especially in access to 
Influence of entertainment media, cognitive styles and demographic variables on students' reading habits in Yaba College of Technology secondary school, Yaba, Lagos

learning resources with greater ease even somewhat controversial.

when their usage in these platforms is still

Research question 3: What is the influence of the dominant cognitive style among Students of Yaba College of Technology Secondary School on their reading habits?

Table 3: Cognitive Style Scale

\begin{tabular}{|c|c|c|c|c|c|c|c|c|}
\hline Questionnaire Items & & $\mathbf{S A}$ & A & D & SD & Tot & Mean & Decision \\
\hline 1. I am socially friendly with my classmates & $\mathrm{F}$ & 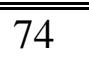 & 48 & 38 & 38 & 198 & 3.82 & Accept \\
\hline while reading. & $\%$ & 37.4 & 24.2 & 19.2 & 19.2 & 100 & & \\
\hline 2. Believing on other persons' or colleagues' & $\mathrm{F}$ & 62 & 45 & 55 & 36 & 198 & 2.62 & Accept \\
\hline $\begin{array}{l}\text { explanation of an idea is my ideal way of } \\
\text { reading. }\end{array}$ & $\%$ & 31.3 & 22.7 & 27.8 & 18.2 & 100 & & \\
\hline 3. I depend on the way others explain a thing & $\mathrm{F}$ & 57 & 52 & 41 & 48 & 198 & 3.11 & Accept \\
\hline while thinking or considering an idea. & $\%$ & 28.8 & 26.3 & 20.7 & 24.2 & 100 & & \\
\hline
\end{tabular}

$\begin{array}{lllllllll}\text { 4. I try as much as possible to stay away } & \text { F } & 73 & 71 & 29 & 25 & 198 & 2.47 & \text { Reject }\end{array}$

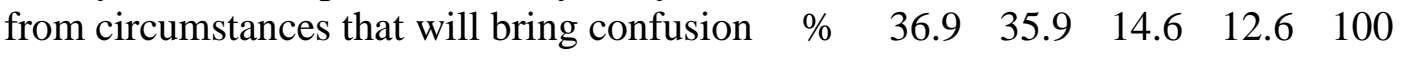
to me while reading (i.e. prefer reading independently).

5. I like reading in a group or keeping companionship while reading.

$\begin{array}{llllllll}\mathrm{F} & 42 & 47 & 58 & 51 & 198 & 2.57 & \text { Accept }\end{array}$

6. I would preferably accomplish something that requires little idea and effort than

$\begin{array}{llllll}\% & 21.2 & 23.7 & 29.3 & 25.8 & 100\end{array}$

$\begin{array}{llllllll}\text { F } & 51 & 53 & 49 & 45 & 198 & 2.83 & \text { Accept }\end{array}$ something challenging my reasoning capacities.

7. I am independent in nature in most cases while reading.

$\begin{array}{llllllll}\text { F } & 61 & 35 & 71 & 31 & 198 & 2.33 & \text { Reject }\end{array}$ $\begin{array}{llllll}\% & 30.8 & 17.7 & 35.9 & 15.7 & 100\end{array}$

8. I would like to learn complex issues that straight forward problems.

$\begin{array}{llllllll}\text { F } & 52 & 53 & 45 & 48 & 198 & 2.45 & \text { Reject }\end{array}$

9. I like to consider reading little everyday than venture too long at a time.

$\begin{array}{llllll}\% & 26.3 & 26.8 & 22.7 & 24.2 & 100\end{array}$

$\begin{array}{llllllll}\text { F } & 82 & 57 & 26 & 33 & 198 & 3.02 & \text { Accept }\end{array}$

10. I like tackling difficult tasks than simple or common ideas while reading.

$\begin{array}{llllllll}\mathrm{F} & 47 & 45 & 53 & 53 & 198 & 2.22 & \text { Reject }\end{array}$

11. I always think as hard as I need to in achieving reading success.

$\begin{array}{llllllll}\text { F } & 86 & 52 & 32 & 28 & 198 & 2.92 & \text { Accept }\end{array}$

12. I am always serious with my reading programmes or time.

$\begin{array}{llllllll}\text { F } & 74 & 93 & 18 & 13 & 198 & 2.68 & \text { Accept }\end{array}$

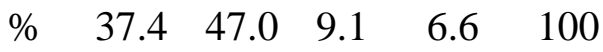

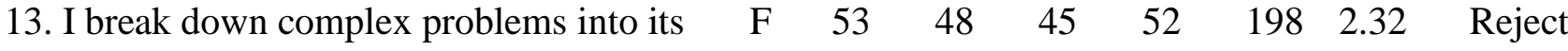
constituent parts while reading.

$\begin{array}{llllll}\% & 26.8 & 24.2 & 22.7 & 26.3 & 100\end{array}$

14. I rely on previous knowledge to advance $\quad \begin{array}{lllllllll} & \mathrm{F} & 59 & 54 & 42 & 43 & 198 & 2.55 & \text { Accept }\end{array}$ 
into complex ideas while reading.

15. I think critically or analyze everything I read before internalizing.

\section{Overall Mean/Cluster Mean (2.69)}

\section{Source: Field Survey, 2019}

Table 3 showed respondents' mean ratings on cognitive style scale. Based on the cutoff point of 2.50 criteria mean of the study, the data on Table 3 therefore revealed that: participants agreed that they are socially friendly with their classmates while reading, they agree that they have believe on other persons' explanation of an idea. Participants also agreed they depend on the way others explain a thing while thinking or considering an idea, and that they like reading in a group or keeping companionship while reading; but disagree trying as much as possible to stay away from circumstances that will bring confusion to them while reading (i.e. prefer reading independently). The results on Table 3 are also indications of collective or group reading habit dominance to independent reading habit. They also accepted that they would preferably accomplish something that requires little idea and effort than something challenging their reasoning capacities and like to consider reading little everyday than venture too long at a time. They agreed that they always think as hard as they need in achieving reading success and they are always serious with $\begin{array}{llllll}\% & 29.8 & 27.3 & 21.2 & 21.7 & 100\end{array}$

$\begin{array}{llllllll}\text { F } & 51 & 52 & 52 & 43 & 198 & 2.51 & \text { Accept }\end{array}$

$\begin{array}{llllll}\% & 25.8 & 26.3 & 26.3 & 21.7 & 100\end{array}$ reading programmes or time. Finally, participants rely on previous knowledge to advance into complex ideas while reading aa well as think critically or analyse everything they read before internalizing. While items 4, 7, 8, 10, and 13 were rejected which implies that they don't depend on the way others explain a thing, though, they are not independent in nature while reading, they will not learn complex issues than straight forward problems, they don't like tackling difficult tasks than simple or common ideas while reading, and that they don't break complex problems into constituent parts while reading. The results are indications that cognitive style of students positively influences their reading habits. This finding supports the idea of Lu (2015) who stated that cognitive styles play important roles in students' learning process upon which reading habits revolves.

\section{Testing of Research Hypothesis}

$\mathbf{H}_{\mathbf{0}}$ : Entertainment media use, Students' cognitive style and demographic variables (age, gender, mothers' and fathers' educational background) do not significantly influence the reading habits 
Influence of entertainment media, cognitive styles and demographic variables on students' reading habits in Yaba College of Technology secondary school, Yaba, Lagos

of Yaba College of Technology Secondary School Students.

Table 4: Pearson's Product Moment Correlation (PPMC) Test

\begin{tabular}{llccc}
\hline & Entertainment & $\begin{array}{c}\text { Reading } \\
\text { Media } \\
\text { Utilization }\end{array}$ & $\begin{array}{c}\text { Demographics } \\
\text { Variables }\end{array}$ \\
\hline Entertainment & Pearson Correlation & 1 & $.696^{* *}$ & $.773^{* *}$ \\
Media & Sig. (2-tailed) & & .000 & .005 \\
Utilization & $\mathrm{N}$ & 198 & 198 & 198 \\
Reading Habit & Pearson Correlation & $.696^{* *}$ & 1 & $.227^{* *}$ \\
& Sig. (2-tailed) & .000 & & .000 \\
Demographics & $\mathrm{N}$ & 198 & 198 & 198 \\
Variables & Pearson Correlation & $.773^{* *}$ & $.227^{* *}$ & 1 \\
& Sig. (2-tailed) & .005 & .000 & 198 \\
\hline
\end{tabular}

**. Correlation is significant at the 0.05 level (2-tailed). Source: Field Survey, 2019

The relationship between demographic variables, entertainment media use and reading habit was investigated using Pearson's correlation coefficient. There was a significant positive correlation between the variables $[\mathrm{r}=0.773 \& 696, \mathrm{n}$ $=198, \mathrm{p}<0.05]$. Thus, the null hypothesis was rejected. This simply means that entertainment media use, cognitive styles and demographic variables significantly influence students' reading habits positively. By implication, these three variables are critical in students reading/study habits and must not only be monitored but be worked upon by management for the attainment of greater academic performance among secondary school students. The positive influence of Entertainment Media use, cognitive styles and demographic variables on students' reading habits implies that regular use of Entertainment Media would improve reading habits of students. This equally connotes that only students with access to Entertainment Media would make use of such media which would considerably improve their interest in reading more regularly and instill good reading habits among them. The finding on one hand, collaborates with the study of Afangideh and Jude (2012) who examined the impact of electronic media asset on learners' reading capability at the Senior Secondary school, Akwa-Ibom State, Nigeria, and found that electronic media help in the advancement of students' academic activities; noting that students who approached TV and radio projects exceeded expectations reasonably than those who didn't have such opportunities. On the other hand, it agrees with the expression that gender, age, 
Influence of entertainment media, cognitive styles and demographic variables on students' reading habits in Yaba College of Technology secondary school, Yaba, Lagos

aptitude, and motivational levels are important variables which may influence the learning process wherein reading habit is central (Mokhtari \& Reichard, 2004; as cited in $\mathrm{Lu}, 2015)$.

\section{Conclusion and Recommendations}

The findings of the study clearly indicate that entertainment media, cognitive styles and demographic variables influence the reading habits of secondary school students. The study therefore, concludes that entertainment media, cognitive styles and demographic variables have significant positive influence on students' reading habits in Yaba College of Technology Secondary School, YabaLagos State. As a result, the following recommendations were made:

Management of Yaba College of Technology Secondary School should ensure that entertainment media as embedded in educational media resources be adequately available for students as it has been found to positively influence their reading habits.

$>$ In like manner, the school library media centre also need to be stocked with relevant and adequate educational media resources not only for ease of access to entertainment media by students but to attract them to library resources use for improved reading habits.

The teacher-librarians should create friendly atmospheres in the school library that would encourage students' visit and increased use of its facilities.

Parents, teachers and Teacherlibrarians should not only as part of teaching and guidance activities pay required attention to the cognitive style of students to enable them have improved understanding and get the best out of them, but to encourage other activities that would support good reading habits among them. Such activities may include: debates, quiz, spelling-bee competitions; as well as the need to put students' demographic variables into consideration since students' individual characteristics differ and has been found to influence their reading habits. These would no doubt help to improve and sustain good reading habits among secondary school students especially in Yaba College of Technology Secondary School, Yaba-Lagos. 
Influence of entertainment media, cognitive styles and demographic variables on students' reading habits in Yaba College of Technology secondary school, Yaba, Lagos

\section{References}

Abbas, J., Aman, J., Nurunnabi, M. \& Bano, S. (2019). The impact of social media on learning behavior for sustainable education: Evidence of students from selected universities in Pakistan. Sustainability, 11 (1683), 1 - 23.

Adegbore, A. M. (2019). Factors influencing students reading habits questionnaire. Retrieved September 16, 2019 from: adebayoadegbore@gmail.com

Adeoye, O., \& Popoola S. O. (2011). Teaching effectiveness, availability, accessibility, and use of library and information resources among teaching staff of schools of nursing in Osun and Oyo State, Nigeria. Library Philosophy and Practice (e-journal). Retrieved October $\quad 10, \quad 2017$ from http://digitalcommons, unl.edu/libphilprac

Adeyanju, E. O. (2016). Picture books as a strategic tool for developing reading culture among Nigerian school children. A Paper Presented at the Nigerian School Library Conference.

Afangideh, M. A. \& Jude, W.I. (2012). Electronic media and students' reading competence in Nigeria

International Journal of Research in Social Sciences, 2(3), 71-88.

Alpern, C. S. S. H. (2009). An investigation of linguistic, cognitive, and affective factors that impact English language learners' performance on a state standardized reading achievement test. A $\mathrm{PhD}$ Thesis at the College of Education, University of Central Florida, Orlando, Florida.

Chou, C. F, \& Hsiao, M. C. (2000). Web compulsion, use, satisfaction, and delight understanding: the Taiwan undergrads' case. PCs and Education, 35(1), 65-80.
Donaldson, T. C. F. (2014). An investigation into reading habits of Texas middle and high school English language arts teachers. A PhD Dissertation in Curriculum and Instruction at the Texas A\&M University-Corpus Christi, Corpus Christi, Texas.

Igbokwe, J. C., Obidike, N. A. \& Ezeji, E. C. (2012). Impact of electronic media on reading ability of school children. Library Philosophy and Practice ISSN 1522-0222. Available at http://unllib.uni.edu/LPP/

Kumara, B. \& Kuma, B. T. S. (2018). Impact of ICT on reading habits of students: A Survey. Asian Journal of Information Science and Technology, 8 (1), $75-79$.

Loan, F. A. (2012). Impact of the internet surfing on reading practices and choices. Webology, 9 (1), June. Retrieved September 17, 2019 from: ttp://www.webology.org/2012/v9n1/a94.ht $\mathrm{ml}$

Lu, W. (2015). Metacognitive reading strategies of ESL learners with different field independent/field dependent cognitive styles. A Masters Dissertation at the Department of English, Faculty of Languages and Linguistics, University of Malaya, Kuala Lumpur.

Majid, S. \& Tan, V. (2007). Understanding the perusing propensities for kids in Singapore. Diary of Educational Media and Library Science, 45(2), 182 - 192.

Menorca, J. C. B., Idos, G. A. G., Manangan, R. J. M. \& Patacsil, J. A. (2017). The impact of gadgets in learning among grade 11 students. A Research Paper Presented to the Faculty of Senior High School Science, Technology, Engineering and Mathematics (STEM) 
Influence of entertainment media, cognitive styles and demographic variables on students' reading habits in Yaba College of Technology secondary school, Yaba, Lagos

Strand Urdaneta City National High School, Urdaneta City.

Onovughe, O. G. (2012). Web use and reading habits of higher institution students. Diary of Emerging Trends in Educational Research and Policy Studies (JETERAPS), 3(1), 11- 15.

Owusu-Acheaw, M. \& Larson, A. G. (2014). Reading habits among students and its effect on academic performance: A study of students of Koforidua Polytechnic. Library Philosophy and

\section{About the authors:}

Beatrice Oluwakemi Adeyokun is Asst. Chief Librarian at Yaba College of Technology Library, Yaba, Lagos, Nigeria. She can be reached at Bolukemi2019@gmail.com

Elkana Oyetunde Adeyanju is Asst. Chief Librarian at Yaba College of Technology Library, Yaba, Lagos, Nigeria. He can be reached at yanjutunde@yahoo.com

George Ogheneruemu Onyenania is Senior Librarian at Yaba College of Technology Library, Yaba, Lagos, Nigeria. He can be reached at onyenaniageorge@yahoo.com
Practice (e-journal). Retrieved September 15,fromhttp://digitalcommons.unl.edu/libp hilprac/1130

Shen, L. (2006). Computer technology and college students' reading habits. Chia-Nan Annual Bulletin, 32 (1), 559 - 572.

Singh, U. (2013). A study of reading habits among LIS students of Indore City. (M.P). Master Degree Dissertation at the Department of Library and Information Science, Devi Ahilya Vishwavidyalaya, Indore. 